\title{
The climatic rhythm and blooms of cyanobacteria in a tropical reservoir in São Paulo, Brazil
}

\author{
Ogashawara, I. ${ }^{a *}$, Zavattini, $J A .^{b}$ and Tundisi, $J$ G. $^{c}$ \\ aDivisão de Sensoriamento Remoto, Instituto Nacional de Pesquisas Espaciais - INPE, Av. dos Astronautas, 1758, \\ CEP 12227-010, São José dos Campos, SP, Brazil \\ bDepartamento de Geografia, Universidade Estadual Paulista “Júlio de Mesquita Filho" - UNESP, Av. 24a , 1515, \\ CEP 13506-900, Rio Claro, SP, Brazil \\ 'Instituto Internacional de Ecologia - IIE, Rua Bento Carlos, 750, CEP 13560-660, São Carlos, SP, Brazil \\ *e-mail: igoroga@gmail.com
}

Received: August 21, 2012 - Accepted: December 5, 2012 - Distributed: February 28, 2014

(With 2 figures)

\begin{abstract}
The present study sought to develop a methodology to analyse water quality based on the concepts and methods of climate and climatology. Accordingly, we attempted to relate hydro- and limnometeorological techniques and methodologies to a rhythmic analysis technique developed within the context of the Brazilian geographical climatology. Our goal was to assess and analyse cyanobacterial blooms, the main index of water quality for the reservoirs of the "Alto Tietê" Basin and, consequently, the Metropolitan Region of São Paulo, an area of high environmental complexity due to its high degree of development and high population density. The meteorological data used were collected by the Institute of Astronomy, Geophysics and Atmospheric Sciences at the University of São Paulo meteorological station, and the limnological data were collected through the Hydrological Monitoring System implemented by SABESP in the Billings and Guarapiranga Reservoirs and the laboratory of the same entity. The rhythmic and integrated analysis showed that the process of cyanobacterial blooms is dependent on a combination of meteorological factors as temperature and wind intensity that may disrupt the stability of the reservoir, providing the conditions necessary for the development of cyanobacteria during the stabilisation process. The pace of the Atlantic Polar Front Entrance during the winter in São Paulo is a limiting factor for the growth of cyanobacteria because of their high frequency, thus maintaining the balance of the reservoir throughout this period. The weather types those could cause a instability in the water column were: Cold Front entrance (66.67\%), conflict between masses (22.22\%) and the Tropical Instability Line (11.11\%). The possibility for prevention and forecasting periods advise when these reservoirs should not be used, mainly with regard to recreational activities.
\end{abstract}

Keywords: geographical climatology, rhythmic analysis, stratification, mixing, cyanobacteria.

\section{O ritmo climático e as florações de cianobactérias em um reservatório tropical em São Paulo, Brasil}

\begin{abstract}
Resumo
O presente trabalho buscou desenvolver uma metodologia para análise da qualidade da água com base em conceitos e métodos do clima e da climatologia respectivamente. Dessa forma, buscou-se relacionar técnicas e metodologias hidrometeorológicas e limno-meteorológicas com a técnica de análise rítmica desenvolvida dentro da climatologia geográfica brasileira para avaliar e analisar as florações de cianobactérias, principal índice de qualidade de água encontrado nos reservatórios da Bacia do Alto Tietê e consequentemente da Região Metropolitana de São Paulo, área de alta complexidade ambiental devido ao seu alto grau de desenvolvimento e a sua alta densidade populacional. Os dados meteorológicos utilizados para o desenvolvimento do trabalho foram coletados a partir da estação meteorológica do Instituto de Astronomia, Geofísica e Ciências Atmosféricas da Universidade de São Paulo e os dados limnológicos foram coletados por meio do Sistema de Monitoramento Hidrológico implantado pela SABESP nos reservatórios de Billings e Guarapiranga assim como os dados laboratoriais da mesma entidade. A análise rítmica e integrada de todos os dados mostrou que o processo de floração de cianobactérias é dependente não apenas de um fator específico, mas de uma combinação de fatores meteorológicos como temperatura e intensidade do vento que podem quebrar a estabilidade do reservatório e proporcionar durante a estabilização as condições necessárias para o desenvolvimento das cianobactérias. Também foi mostrado como o ritmo de entrada de Frentes Polares Atlânticas, durante o inverno paulistano, é um fator que limita o crescimento das cianobactérias devido à sua alta frequência, mantendo o reservatório desequilibrado
\end{abstract}


por todo o período. Os tipos de tempo que podem causar instabilidade na coluna da água foram identificados com: entrada de Frentes Frias (66,67\%), conflitos entre massas (22,22\%) e Linha de Instabilidade (11,11\%). Mostra-se assim a importância do trabalho para a prevenção e previsão de períodos inapropriados para o uso desses reservatórios principalmente para atividade de recreação.

Palavras-chave: climatologia geográfica, análise rítmica, estratificação, mixing, cianobactérias.

\section{Introduction}

The effect of climate on aquatic environments was revealed in 1920 by the geographer Emmanuel de Martonne in his book Traité de géographie physique: climat, hydrographie, relief du sol, biogéographie in which he wrote that the climate could be an important factor for the stability of the aquatic environment (Martonne, 1920). The vertical structure of tropical reservoirs is susceptible to stratification and the mixing process originating from weather events, as documented in Tundisi et al. (2004, 2010) and Moraes et al. (2010). These studies showed that, according to the variability of wind stress and regimes, aquatic ecosystems present several responses in their physical, chemical, and biological variables.

However, these studies considered only the wind (direction and intensity), as the weather parameters and their statistical data do not characterize a climate because a it depends on a diverse number of meteorological parameters. As demonstrated by Court (1957), "climate is not static", which means that, in some situations, climatic characteristics based on the averaged courses of meteorological elements appear to have restricted use because they do not provide any information regarding the correlations between them. This fact was previously observed by Ward (1914) in a paper published in the Annals of the Association of American Geographers in which he wrote that the annual, monthly and diurnal averages of the different climatic elements, when given numerically or even when charted, are often misleading. These data do not show how and why the conditions that they aim to represent actually occurred, and they may not explain what actually did occur, being that it is the actual and not the normal that we really experience. The same view is accepted by the American geographer William Morris Davis: according to Skaggs (2004, p. 446), "[...] it is clear that Davis did not really approve of climatological research based on a definition of climate as average weather."

In Europe the same view has emerged through the French geographer Maximilien Sorre (1951) who elaborated a new definition of climate based on the advances of dynamic meteorology in a review of Hann's concept, considering the local characteristics of the climatic complex. In this way, Sorre (1951, p. 14) defines the climate as "[...] a series of atmospheric states in a specific place in its habitual succession." Here, atmospheric states are defined as the types of meteorological weather and their complexion, association and dynamic characteristics; their seasonal behaviour in a specific location is essential for the definition of the local and regional climate.

Since Sorre's definition of climate, French climatology advanced with Pédelaborde's studies $(1957,1970)$ in which he analyses the types of weather in the Paris Basin. In a paper titled "Introduction à l'étude scientifique du climat", according to Zavattini (2000), Pédelaborde writes that climatology studies the characteristics of the atmosphere's interaction with the Earth's crust, specifically regarding its spatial distribution.

In Brazilian geography, the concept of climate elaborated by Sorre (1951) was also the starting point for the studies of Monteiro (1969, 1971, 1976a, 1976b, 1991). However, in contrast to Pédelaborde (1970), the break of Hann's definition of climate for Monteiro was a paradigm break which could be done with the "totality of weather types" and the rhythm, meaning the constant succession of atmospheric states and their manifestations, in the sense that they attempt to return to the same states.

The concept of rhythm discussed by Monteiro (1969) is the essence of the dynamic analysis of surface circulation in relation to the impacts and interactions with the socioenvironmental aspects. To visualise these interactions, Monteiro (1969) proposed a technique called "rhythm analysis", which aims to distinguish the types of weather and, thus, to follow their rhythms, together with the accompanying measurements collected by a meteorological station. Without any reference to the Brazilian geography literature, Edenson (2010) wrote about the rhythm analysis proposed by Lefebvre (2004), describing the method as particularly useful in investigating the patterning of a range of multiscalar temporalities. These temporalities are calendrical (diurnal and lunar), lifecycle, somatic and mechanical, and their rhythms provide an important constituent of the experience and organisation of social time.

To understand the influence of the weather on cyanobacterial blooms, Tundisi et al. (2010) propose a mechanism of the functioning of reservoirs and lakes of southeastern Brazil that is related to the patterns of instability during cold fronts and stability in the absence of cold fronts as an alternative to a model of phytoplankton succession for lakes and reservoirs that is based on the instability of the water column. However, this approach only uses one type of weather, and for a model, it is important to analyse the succession of the weather types over the course of a long period of time.

Here, we describe the use of rhythm analysis, a technique of Brazilian Geographic Climatology, to identify and discuss the impact of the weather types, as classified during the year 2009, on the cyanobacterial blooms in the Billings Reservoir located in the city of São Paulo, Brazil. The implications of this rhythmical process on the reservoir are discussed in addition to the possible impacts on the management strategies for drinking water reservoirs in the Metropolitan Region of São Paulo. 


\section{Material and Methods}

The study was conducted in the São Paulo Metropolitan Region in 2009. The climatologic data (see below) were collected by the meteorological station of the Institute of Astronomy, Geophysics and Atmospheric Sciences at the University of São Paulo (IAG/USP), located in the "Parque das Fontes do Ipiranga", Southern region, Água Funda, São Paulo - SP. Geographically, this area corresponds to latitude $23^{\circ} 39^{\prime} \mathrm{S}$ and longitude $46^{\circ} 37^{\prime} \mathrm{W}$. To the south are the reservoirs of Billings and Guarapiranga, which are responsible for supplying water to the city. According to Moraes et al. (2010), the maximum depths in each reservoir are 25 and $13 \mathrm{~m}$, for Billings and Guarapiranga respectively, and are thus considered to be shallow reservoirs.

\subsection{Materials}

The data collect by the meteorological station of IAG/ USP refer to the following climatic factors: atmospheric pressure (Micro-Barograph, Fuess), air temperature (Assmann's Psychrometer, Fuess and Thermograph 79, Fuess), air humidity (Hydrograph, Fuess), duration of sunshine (Campbell-Stokes Heliograph, Lambrecht), precipitation (Hellmann pluviograph, Lambrecht), wind direction and intensity (Anemograph "Universal" 82b, Fuess) and cloudiness (IAG, 2012).

Regarding the limnological data for the Billings Reservoir, we used two stations of the Company of Basic Sanitation of the State of São Paulo (SABESP). One is a System of Hydrologic Monitoring (SMH), which collects the physicochemical parameters every 30 minutes using sensors fitted in the units; the other station is a biochemical laboratory, which performs water analyses approximately every 3 days. The parameters collected by the SMH include the $\mathrm{pH}$, temperature, conductivity, oxidation-reduction potential, turbidity and dissolved oxygen. The SMH used the multiparametric probe (YSI) to collected the limnologic data; the telemetric and data storage system were developed by the Clean Environment Brasil. We used only the data for the density of the cyanobacteria from the laboratory analysis following the method proposed by CETESB in the Technical Note L5.303 where specialised counting chambers of a known volume are used in conjunction with a grid system to enable examination of a known area of the chamber, and corresponding volume of sample. It was used the Sedgwick-Rafter chamber with an upright microscope. The Sedgwick-Rafter chamber is etched with a calibrated grid of $50 \times 20$ equal sized squares $\left(1 \mathrm{~mm}^{2}\right)$ (CETESB, 2005).

To generate the rhythm analysis proposed by the Brazilian Geographic Climatology, we used support data to understand the atmospheric circulation and dynamics. The following data were used to characterise the daily weather types: 340 synoptic analyses from the Center for Weather Forecasting and Climate Studies (CPTEC) from the National Institute of Spatial Research (INPE); 739 synoptic maps from the Brazilian Navy; and 1453 satellite images of the sensor GOES 10, also available at the CPTEC/INPE website: http://www.cptec.inpe.br.

\subsection{Methods}

The Brazilian Geographical Climatology Rhythm Analysis was developed from the data obtained from the IAG/USP meteorological station. By integrating all of these data, it was possible to construct a chart relating the daily variations of the climatic elements to the aspects of the atmospheric dynamic, which generates the process of mixing and stability in the water column of the reservoir. Furthermore, the Brazilian Geographical Climatology Rhythm Analysis was associated with the limnological series of parameters obtained from 2 different stations: the SABESP's automatic station of hydrologic monitoring and SABESP's physicochemical laboratory, both located at the Billings Reservoir.

The development of the rhythm analysis began with the daily spatialization of the data collected from the meteorological station. The weather parameters were distributed as follows. 1) The atmospheric pressure data from 12:00 $\mathrm{h}$ to $00: 00 \mathrm{~h}(\mathrm{GMT})$ were plotted as solid lines; these times were chosen because they coincide with those analysed in the synoptic maps from the Brazilian Navy. 2) The maximum and minimum temperatures were represented by a bar connecting them, and the temperature at 15:00 h (GMT) was expressed as a continuous line. 3) The maximum and minimum humidity and that at 15:00 h (GMT) were all expressed as continuous lines. 4) The sunshine was expressed as a continuous line, representing the duration of the solar radiance for one day. 5) The precipitation was expressed in a column chart showing the amount (in $\mathrm{mm}$ ) of daily rain. 6) The wind direction at 09:00 $\mathrm{h}$ (GMT) and 15:00 h (GMT) was classified using letters, and the wind intensity at 09:00 h was classified numerically. 7) The cloudiness was expressed graphically with full coverage, partially or nonexistent.

To elaborate the classification of the weather types for the rhythm analysis, the classes of atmospheric systems identified by Monteiro (1973) were used, as follows: 1) Frontal Systems - Polar Atlantic Front (FPA), Reflex Polar Front (FPR), Polar Atlantic Front in Dissipation (DIS), Occlude Polar Atlantic Front (OCL), Repercussion of Polar Atlantic Front (REP), Stationary Polar Atlantic Front (EST), and Warm Front; 2) Individualised Systems - Tropical Instability Line and Atlantic Intertropical Convergence Zone; and 3) Air Masses - Polar Atlantic mass (mPA), Old Polar mass (mPV), Continentalized Old Polar mass (PVC), Tropical Atlantic mass (mTA), Continentalized Tropical Atlantic mass (TAC), Tropical Continental mass (mTC), and Equatorial Continental mass (mEQ).

Zavattini (1990) synthesized the system according to this classification: 1 ) South Currents $=\mathrm{mPA}+\mathrm{mPV} / \mathrm{PVC}$ + FPA/OCL/DIS/EST + FPR; 2) East Currents = mTA + TAC + Tropical Instability Line + Warm Front + REP; 3) North Current $=m E Q$; and 4) West Current $=$ mTC.

\section{Results}

Figure 1 demonstrates the cyanobacterial density (cel/mL) in the Billings Reservoir each week during 2009. The following behaviour was noted: a) the highest 


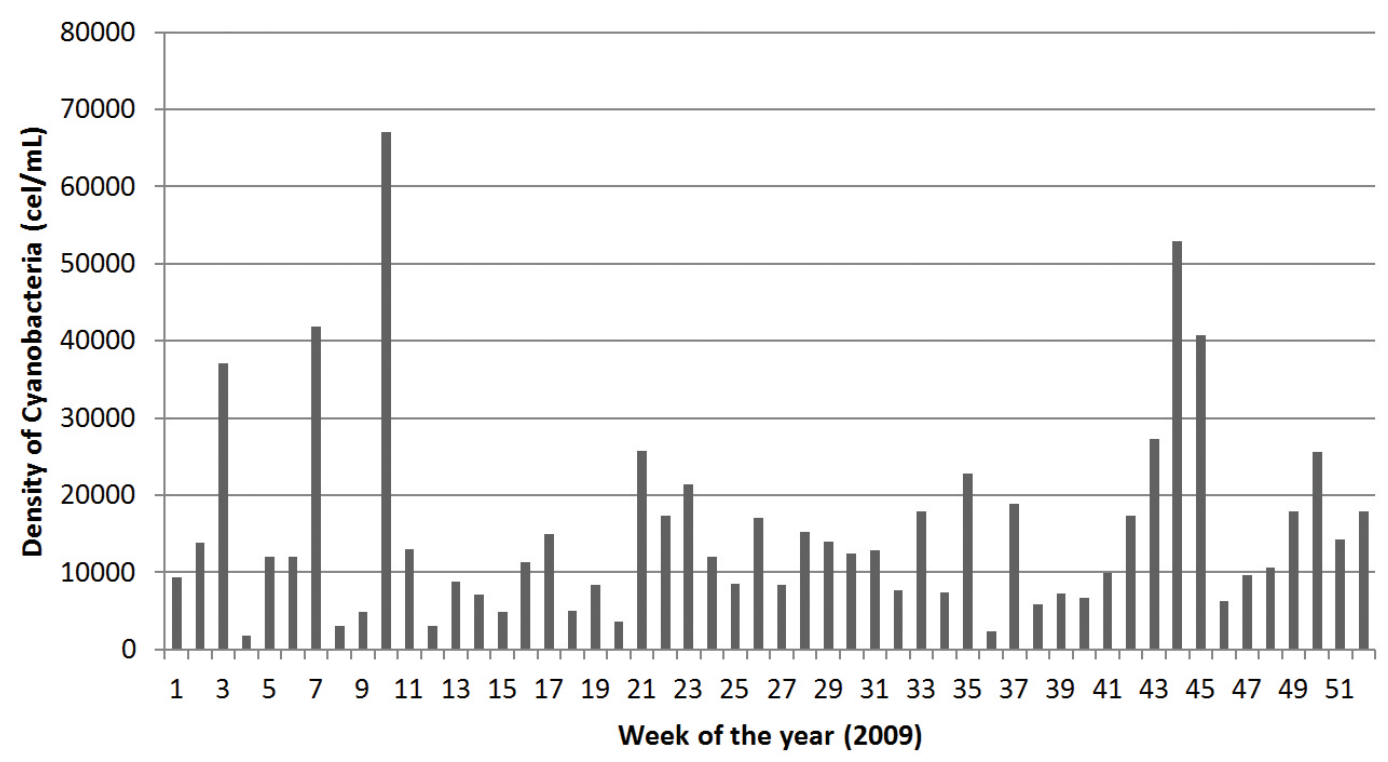

Figure 1. Weekly cyanobacterial density (cel/mL) in Billings Reservoir for 2009.

cyanobacterial density levels occurred during weeks 1 to 12 (summer) and 43 to 52 (spring and early summer), levels that were much higher than the density permitted by the Brazilian Council for the Environment (CONAMA) $\mathrm{n}^{\circ} 357 / 2005$ (Brasil, 2005), which is 20,000 cells per mL; b) the lowest concentrations levels were registered during weeks 13 to 20 (early autumn); and, c) the concentration was slightly higher than the limit established by law during weeks 21 to 42 (late autumn, winter and early spring).

Using the Integrated Chart (Rhythm Analysis + Limnologic time series) in Figure 2, when the analysis scale is changed to daily, the most active current in the first trimester is revealed to be the "East Current". This current controlled the atmospheric conditions for more than a half of the period $(55.55 \%)$ and was the responsible for the stability of the reservoir for 45 days (50\%) under the influence of a mTA. The resulting elevated air temperature and pressure generated the specific characteristics for the occurrence of 5 events of critical (more than the limit) cyanobacterial blooms during this period. In general, the critical cyanobacterial blooms during the first trimester of 2009 were associated mainly with a mTA $(80 \%)$, compared to a mTC (20\%); interestingly, all of the blooms occurred after a disturbance in the water column caused by a Tropical Instability Line (20\%), an EST (20\%) and a FPA (60\%). The most critical events, with a density of cyanobacteria of more than $30000 \mathrm{cel} / \mathrm{mL}$, were related to the Instability Line $(34324.5 \mathrm{cel} / \mathrm{mL})$ and to the Stationary Polar Atlantic Front $(37761.9 \mathrm{cel} / \mathrm{mL})$. These results demonstrate that the mechanism of mixing and stratification proposed by Tundisi et al (2010) could occur both with the front enters and also with other weather types that disturb the water column. Within this context, the successions of weather types which cause the increase in the cyanobacterial density are mainly related to a meeting of a Tropical Equatorial mass or Equatorial Continental mass with a Tropical Instability Line or Polar Atlantic Front and its derivations.

During the second trimester of 2009, the control of the atmospheric conditions above the São Paulo Metropolitan Region occurred due to the "South Current", as it was predominant $(76.92 \%)$ during this period. The strong influence of the Polar Atlantic mass and Old Polar mass resulted in low temperatures and few precipitation events during this trimester. Moreover, the predominance of the Polar masses resulted in reductions in the cyanobacterial levels, with no density being higher than the limit proposed by the MMA (Brasil, 2005). The two highest densities are associated with Polar masses: one with the Atlantic Polar mass and the other with the Old Polar mass. Interestingly, the first bloom was preceded by a meeting of a Tropical Atlantic mass and an Atlantic Polar mass, which caused precipitation, increased air humidity and pressure and reductions in the air temperature. Such a confrontation generates a mixing process in the water column during the Atlantic Polar mass, causing stratification and the growth of cyanobacteria. In the second instance, the bloom was preceded by an Atlantic Polar Front and followed the same process as identified in the first trimester. In this trimester, the sequence of weather types caused less of an impact on the blooms of cyanobacteria and was mainly related to the low temperatures originating from the constant presence of the Polar air masses. However, the front still acted as a promoter of the mixing process in addition to the meeting of the air masses of the mTA and mPA.

In the third trimester, the frontal events became more active in the area, and the Polar air masses expanded the influence of the "South Current" (77.17\%) because it effected a continuous supply of cold air from the south of the continent. The frontal events represented $15.22 \%$ of the weather types of the period while the Polar masses 


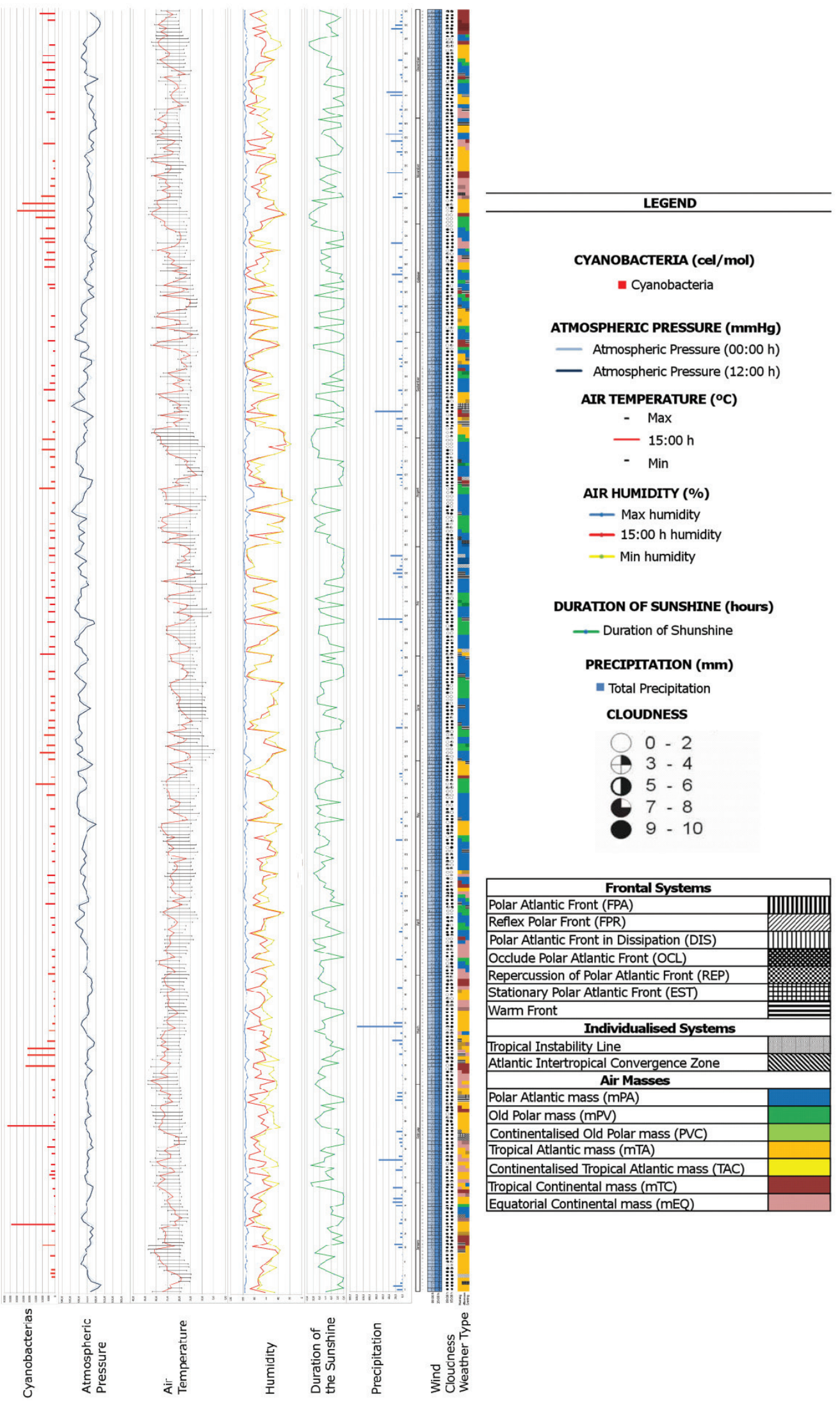

Figure 2. Rhythm Analysis integrated with the limnological analysis for Billings Reservoir for 2009. 
Table 1. Cyanobacterial blooms higher than the limit established by the MMA (Brasil, 2005).

\begin{tabular}{lcccccc}
\hline \multicolumn{1}{c}{ Trimester } & \multicolumn{5}{c}{$\mathbf{1}$} & \multicolumn{4}{c}{$\mathbf{4}$} \\
\hline Density & 34324.5 & 37761.9 & 23450.2 & 21771.9 & 21809.1 & 29853 \\
Weather Type & mTA & mTA & mTC & mTA & mTA & mTA \\
Previous event & Instability & Cold Front & Cold Front & Cold Front & Cold Front & Conflict \\
\hline
\end{tabular}

represented $62 \%$. The rhythm of the occurrence of these systems provided instability in the water column, resulting in the lowest density levels of the cyanobacteria during the year. The highest density $(12,556.4 \mathrm{cel} / \mathrm{mL})$ occurred during an Old Polar mass after the entrance of a Polar Atlantic Front. However, the duration was longer when compared to the other trimesters because during a Polar Atlantic mass, the temperature decreases such that growth of cyanobacteria is not allowed, even if the reservoir is stratified. Therefore, this rhythm of cold front entry during this period, as associated with the weather type sequences, is responsible for the instability in the water column and the low cyanobacterial density during the period.

In the fourth trimester of 2009, the "South Current" was still actively circulating, as shown by its participation rates in the São Paulo Metropolitan Region (45.65\%); however, the "East Current" also has a considerable participation (32.6\%). This fact influenced the occurrence of Tropical Atlantic masses during this period, which are the responsible for the increase in the temperature and precipitation; the "East Current" also provided an increase in the number of air mass conflicts. The influence of the "South Current" was reduced with regard to the duration of the Polar air masses, but it was still active in the frontal events. Due to the presence of these two currents, the density of the cyanobacteria also increased during this period, with one long bloom that was higher than the limit established by the MMA (Brasil, 2005). The highest density in the period $(29,853 \mathrm{cel} / \mathrm{mL})$ occurred during a Tropical Atlantic mass after a conflict between an Equatorial Continental mass and a Polar Atlantic mass and continued until the appearance of a Tropical Instability Line. Similar to the rhythm in the first trimester, the blooms occurred during the warmer weather types and after a instability in the water column. In general, the fourth trimester appears to be a transition period between the predominance of the "South Current" and "East Current".

In general, the intense activities of Polar air generated numerous frontal events during most of 2009 (second, third and part of the fourth trimesters), events that were mainly responsible for the instability of the water column and the low density of cyanobacteria. The seven highest densities were caused by 3 types of events: a Cold Front entrance $(66.67 \%)$, conflict between masses $(22.22 \%)$ and the Tropical Instability Line (11.11\%). However, the 4 blooms that attained values higher than the established limit were generated from the same 3 types of events: a Cold Front entrance $(66.67 \%)$, conflict between masses $(16.67 \%)$ and the Tropical Instability Line (16.67\%). These results are presented in Table 1. The blooms of cyanobacteria can be correlated to the active presence of the "East Current" because in the trimesters that are dominated by the "South
Current", there were no cases of a cyanobacterial density higher than the limit.

\section{Discussion}

The integration of the limnological series of data to the Rhythm Analysis of Brazilian Geographic Climatology provided an understanding of the function of weather events with regard to the growth of cyanobacteria. In this study, the meteorological parameters were evaluated through the use of the rhythm paradigm based on the succession of weather types, which assisted us to confirm that the rhythm impose by the climate also interferes with the rhythm of cyanobacterial growth.

The results obtained through the use of the Integrated Chart confirmed the mechanism proposed by Tundisi et al. (2010), classified the weather types acting in São Paulo in the year of 2009 and identified their interactions with the cyanobacterial blooms. The succession of weather types in 2009 leads to the climatic rhythm of each trimester of the analysed year as well as the rhythm of cyanobacterial blooms during the period. The rhythm of this process can be an important parameter during the elaboration of a predictive model of water quality and dynamics that can be used by policy makers as a tool for the management of reservoirs. This is particularly important for the Billings Reservoir, which supplies drinking water to the São Paulo Metropolitan Region. According to Tundisi et al. (2010), policy makers should take into account both water quantity and water quality if they want to negotiate water use in the São Paulo Metropolitan Region.

In this way the use of climatic data allows the policy makers and the reservoir's manager to develop a predictive model for use as a tool for management. With these results it is important to consider the predictive capacity given by the interaction of weather types with the water column dynamic, which will reflect costs of treatment and water availability.

The investigation of this specific geographic region with respect to environmental planning and analysis is a critical task and is presented as an open field for new experimentation, including climatologic studies.

Acknowledgments - The authors thank FAPESP (Fundação de Amparo a Pesquisa do Estado de São Paulo) for the scholarship obtained through process number 2010/14803-0.

\section{References}

Brasil. Ministério do Meio Ambiente - MMA, 2005. Resolução CONAMA n ${ }^{\circ} 357$, de 17 de Março de 2005. Dispõe sobre classificação dos corpos de água e diretrizes ambientais para o 
seu enquadramento, bem como estabelece as condições e padrões de lançamento de efluentes, e dá outras providências. Diário Oficial da República Federativa do Brasil, Brasília, 18 mar., 23 p.

Companhia de Tecnologia de Saneamento Ambiental - CETESB, 2005. Norma Técnica L5.303: fitoplâncton de água doce: métodos qualitativo e quantitativo: método de ensaio. São Paulo: CETESB. Available from: $<$ http://www.cetesb.sp.gov.br/userfiles/file/servicos/ normas/pdf/L5303.pdf $>$. Access in: 26 Set. 2012.

COURT, A., 1957. Climatology: Complex, dynamic, and synoptic. Annals of the Association of American Geographers, vol. 47, no. 2, p. 125-136. http://dx.doi.org/10.1111/j.1467-8306.1957.tb01528.x.

EDENSON, T., 2010. Geographies of rhythm: nature, place, mobilities and bodies. Farnham: Ashgate Publishing. 241 p.

Instituto de Astronomia, Geofísica e Ciências Atmosféricas - IAG, 2012. Instrumentos e procedimentos. Available from: $<\mathrm{http}: / / \mathrm{www}$. estacao.iag.usp.br/instrumentos.php>. Access in: 26 Set. 2012.

LEFEBVRE, H., 2004. Rhythmanalysis: space, time and everyday life, trans. S. Elden and G. Moore. London: Continuum. 169 p.

MARTONNE, E., 1920. Traité de géographie physique: climat, hydrographie, relief du sol, biogéographie. Paris: Armand Colin. $922 \mathrm{p}$.

MONTEIRO, CAF., 1969. A frente polar atlântica e as chuvas de inverno na fachada sul-oriental do Brasil: contribuição metodológica à análise rítmica dos tipos de tempo no Brasil. São Paulo: IGEOG/USP. 68 p.

MONTEIRO, CAF., 1971. Análise ritmica em climatologia: problemas da atualidade climática em São Paulo e achegas para um programa de trabalho. São Paulo: IGEOG/USP. 21 p.

MONTEIRO, CAF., 1973. A dinâmica climática e as chuvas no estado de São Paulo: estudo geográfico sob forma de atlas. São Paulo: IGEOG/USP. 129 p.

MONTEIRO, C.A.F., 1976a. Teoria e clima urbano. São Paulo: IGEOG-USP. 181 p. Série teses e monografias - IGEOG-USP, no. 25 .

MONTEIRO, CAF., 1976b. O clima e a organização do espaço no estado de São Paulo: problemas e perspectivas. São Paulo: IGEOG-USP. 54 p. Série Teses e monografias, no. 28.

MONTEIRO, CAF., 1991. Clima e excepcionalismo: conjecturas sobre o desempenho da atmosfera como fenômeno geográfico. Florianópolis: UFSC. 241 p.
MORAES, MA., CASTRO, WAC. and TUNDISI, JG., 2010. Climatologia de frentes frias sobre a Região Metropolitana de São Paulo (RMSP), e sua influência na limnologia dos reservatórios de abastecimento de água. Revista Brasileira de Meteorologia, vol. 25 , no. 2 , p. $205-217$

PÉDELABORDE, P., 1957. Lê climat du bassin parisien: essai d'une méthode rationelle de climatologie physique. Paris: Medicis.

PÉDELABORDE, P., 1970. Introduction à l'étude scientifique du climat. Paris: Sedes.

SKAGGS, RH., 2004. Climatology in American geography. Annals of the Association of American Geographers, vol. 94, no. 3, p. 446-457. http://dx.doi.org/10.1111/j.1467-8306.2004.00407.x.

SORRE, M., 1951. Le climat et l'homme. Le Climat. In SORRE, M. Les fondements de la gëographie humaine: essai d'une écologie de l'homme. Paris: Armand Colin. p. 13-43.N

TUNDISI, JG., MATSUMURA-TUNDISI, T., ARANTES JÚNIOR, JD., TUNDISI, JE., MANZINI, NF. and DUCROT, R., 2004. The response of Carlos Botelho (Lobo, Broa) Reservoir to the passage of cold fronts as reflected by physical, chemical, and biological variables. Revista Brasileira de Biologia = Brazilian Journal of Biology, vol. 64, no. 1, p. 177-186. http://dx.doi.org/10.1590/ S1519-69842004000100020. PMid:15195377

TUNDISI, JG., MATSUMURA-TUNDISI, T., PEREIRA, KC., LUZIA, AP., PASSERINI, MD., CHIBA, WAC., MORAIS, MA. and SEBASTIEN, NY., 2010. Cold fronts and reservoir limnology: an integrated approach towards the ecological dynamics of freshwater ecosystems. Revista Brasileira de Biologia = Brazilian Journal of Biology, vol. 70, no. 3, p. 815-824. http://dx.doi.org/10.1590/ S1519-69842010000400012. PMid:21085786

WARD, R., 1914. The weather element in American climates. Annals of the Association of American Geographers, vol. 4, no. 1, p. 3-54. http://dx.doi.org/10.1080/00045601409356976.

ZAVATTINI, JA., 1990. A dinâmica atmosférica e a distribuição das chuvas no Mato Grosso do Sul. São Paulo: Universidade de São Paulo. 223 p. Tese de Doutorado em Geografia Física.

ZAVATTINI, JA., 2000. O paradigma da análise rítmica e a climatologia geográfica brasileira. Geografia (Rio Claro), vol. 25 , no. 3, p. 25-43. 